\title{
Ortaokul Öğrencilerinin Akademik Öz Yeterlik Algıları ve Okuma Stratejileri Bilişüstü Farkındalıkları*
}

\author{
Canan KOÇ* ${ }^{* *}$, Aysel ARSLAN ${ }^{* * * *}$
}

Öz: Bu araştırmada ortaokul öğrencilerinin akademik öz yeterlik algılarının ve okuma stratejileri bilişüstü farkındalıklarının sınıf düzeyi, cinsiyet ve anne baba eğitim durumu değişkenlerine göre incelenmesi; akademik öz yeterlik algısı ile okuma stratejileri bilişüstü farkındalık düzeyleri arasındaki ilişkinin belirlenmesi amaçlanmaktadır. Tarama modelinin kullanıldığı araştırmanın örneklemini Sivas Merkezde bulunan ortaokullardan 539'u kız, 520'si erkek toplam 1059 öğrenci oluşturmaktadır. Araştırmanın verileri Akademik Öz Yeterlik Ölçeği ve Okuma Stratejileri Bilişsel Farkındalık Ölçeği ile toplanmıştır. Bu çalışmada elde edilen verilerin analizi sonucunda, ortaokul öğrencilerinin akademik öz yeterlik algılarının ve okuma stratejileri bilişüstü farkındalık alt boyutlarının sınıf ve cinsiyete göre anlamlı düzeyde farklılık gösterdiği belirlenmiştir. Öğrencilerin akademik öz yeterlik algıları anne ve baba eğitim durumlarına göre anlamlı farklılık gösterirken okuma stratejileri bilişüstü farkındalık alt boyutlarında anlamlı bir farklılık saptanmamıştır. Akademik öz yeterlik ile okuma stratejileri bilişüstü farkındalık alt boyutları arasında pozitif yönde anlamlı ilişki bulunmaktadır.

Anahtar Kavramlar: Öz yeterlik, bilişüstü farkındalık, okuma stratejileri

\footnotetext{
* Bu çalışma, 28-31 Mayıs 2015 tarihlerinde Muğla'da düzenlenen VII. Uluslararası Eğitim Araştırmaları Kongresi'nde sözlü bildiri olarak sunulmuştur.

** Doç. Dr., Cumhuriyet Üniversitesi Eğitim Fakültesi, Eğitim Bilimleri Bölümü, Eğitim Programları ve Öğretim, Sivas

**** Yukksek Lisans Öğrencisi Cumhuriyet Üniversitesi Eğitim Fakültesi, Eğitim Bilimleri Bölümü, Eğitim Programları ve Öğretim, Sivas
} 


\title{
Academic Self-Efficacy Perceptions and Metacognitive Awareness of Reading Strategies of Secondary School Students
}

\begin{abstract}
Absract: This research aims to investigate the academic self-efficacy perceptions and metacognitive awareness of reading strategies of secondary school students by class grade, gender, and parent's educational status variables and to determine the correlation between the academic self-efficacy perception and the metacognitive awareness of reading strategies. The research incorporated the screening model and the sample of it comprised of 1059 students in total, 539 females and 520 males. The data of the research were collected via Academic SelfEfficacy Scale and Reading Strategies Cognitive Awareness Scale. Based on the analysis of the data from the research, a significant difference was found for class grade and gender at academic self-efficacy perceptions and metacognitive awareness of reading strategies subdimensions of the secondary school students. While academic self-efficacy shows significant difference by parent's educational status, no significant difference was found at subdimensions of metacognitive awareness of reading strategies. There exists a medium level positive correlation between the academic self-efficacy and the metacognitive awareness of reading strategies sub-dimensions.
\end{abstract}

Key Words: Self-efficacy, metacognitive awareness, reading strategies 


\section{Giriş}

Öz yeterlik kavramı günümüzde eğitim alanında yapılan pek çok araştırmaya konu edilmiştir. Eğitim araştırmalarında öz yeterlik kavramının bu kadar öne çımasının temel nedeni, öğrencilerin öz yeterlik algılarının güdü ve öğrenme üzerindeki olumlu etkisi (Schunk ve Pajares, 2002; Schunk ve Mullen, 2012; Zimmerman, 2000) ve aynı zamanda öğretmenlerin öz yeterlik algılarının da öğrencilerin başarısını doğrudan etkileyen bir öğretmen özelliği olmasıdır (Caprara, Barbaranelli, Steca ve Malone, 2006; TschannenMoran ve Johnson, 2011). Yani hem öğrencinin hem de öğretmenin öz yeterlik algis1 akademik başarının ve diğer öğrenme ürünlerinin anahtarı olarak görülmektedir.

Öz yeterlik kavramı, ilk kez Bandura'nın Sosyal Bilişsel Kuramında ortaya konmuş ve bireylerin istenen düzeyde performans gösterme yeteneklerine ilişkin inançları olarak tanımlanmıştır (Bandura, 1994). Öz yeterlik inançları, bireylerin nasıl hissedeceklerini, düşüneceklerini, kendilerini nasıl güdüleyeceklerini ve nasıl davranacaklarını etkilediği için bireylerin kullandıkları yetenek ve becerilerden çok daha önemli görülmektedir (Bandura (1994). Bireylerin bir işi başarmak için gerekli olan bilgi ve becerilere sahip olmaları yeterli olmamakta, aynı zamanda zorlayıcı ve tipik koşullarda bile istenen davranışları başarılı bir şekilde gerçekleştirebileceklerine dair inançlarının da olması gerekmektedir (Zimmerman, 2000). Kuzgun'un (2000) belirttiği gibi, öz yeterlik inanc1, bireyin sahip olduğu kapasitenin, yaptığı işlerdeki başarılarının, güdülerinin ve öz kavramını oluşturan diğer öğelerin bir bileşkesi olup; her türlü davranış girişiminin başlayıp başlamayacağını, başlayan bir davranışın ise devam edip etmeyeceğini belirleyici güce sahiptir (Akt. Hazır Bıkmaz, 2006).

Bandura (1999), öz yeterlik algısının dört temel kaynaktan oluştuğunu belirtmektedir. Bunlar doğrudan yaşantılar, dolaylı yaşantılar, sosyal ikna ve duygusal-fizyolojik 
durumlardır. Güçlü bir öz yeterlik algısı oluşturmak için bunlardan en etkili olanı doğrudan deneyimlerdir. Başarılı olmak bireylerde kişisel yeterliliklerine ilişkin güçlü bir inanç oluştururken başarısızlıklar ise özellikle öz yeterlik algısı tam olarak oluşmadan önce ortaya çıkmışsa öz yeterliği azaltmaktadır (Bandura, 2002). Bireylerin öz yeterlik inançları, başkalarının eylemlerinin gözlemlenmesini içeren dolaylı yaşantılar yoluyla da oluşmaktadır. Dolaylı yaşantılarda modeller öz yeterliğin gelişiminde güçlü bir rol oynamaktadırlar (Usher ve Pajares, 2006). Öğrenciler, benzer yetenekte olduğu kabul edilen akranların başarılarının veya başarısızlıklarının gözlemlenmesi, kendi eylemlerinin sonuçları ile gözlemledikleri akranlarınınkini karşılaştırma yoluyla öz yeterlik algılarını oluşturur ve geliştirirler (Pajares, 2012). Öz yeterliğin gelişmesinde üçüncü kaynak sosyal iknalardır. Sosyal iknanın öz yeterlik üzerindeki etkisi, iknanın içeriği ve niteliği ile ikna edicilerin özelliklerine bağlıdır. Olumlu iknalar öz yeterliği desteklemede ve güçlendirmede işe yararken olumsuz iknalar öz yeterliği zayıflatmaktadır (Schunk ve Pajares, 2009). Ebeveynler, öğretmenler, akranlar ve önemli görülen (ya da bazen önemsiz) başka bireylerden alınan sözlü ve sözsüz mesajlar, öğrencilerin akademik yeteneklerine ilişkin güvenlerini arttırma ya da azaltma gücüne sahiptir (Pajares, 2012). Öz yeterliğin gelişiminde etkili olan bir diğer kaynak ise kayg1, stres gibi fizyolojik ve duygusal durumlardır (Bandura, 1997). Bireyler kendi öz yeterliklerini, bir eylem üzerinde düşünürken yaşadıkları duygusal durum aracılığıyla ölçebilirler. Öz yeterliği artırmanın diğer bir yolu da fiziksel ve duygusal iyi oluşu arttırarak olumsuz duygusal durumları azaltmadır (Schunk ve Pajares, 2009).

Öz yeterlik algısı; duygusal, bilişsel, güdüsel süreçlerin, davranışsal göstergelerin ya da bireylerin yaşadıkları ve çalıştıkları sosyal çevrenin bir sonucu olarak gelişmektedir. Örneğin, okulda öğrenciler duygularını ve düşüncelerini değiştirebildiğinde (kişisel 
faktörler), öğretmenler etkili sınıf yapıları kullandığında (çevresel faktörler), öğrenciler öz düzenleme uygulamalarını geliştirdiğinde (davranış), öğrencilerin öz yeterlik inançları gelişebilmektedir (Usher, 2009).

Öz yeterlik kavramı akademik bağlamda, akademik öz yeterlik olarak ifade edilmekte ve Bandura (1977) tarafindan, bireylerin belirlenmiş eğitimsel performans türlerine ulaşmak için eylem sürecini düzenlemesine ve uygulamasına ilişkin becerileri hakkındaki yargısı olarak tanımlanmaktadır. Akademik öz yeterlik, bireylerin bir akademik işi istenen düzeyde başarılı bir şekilde başarabileceklerine ya da belli bir akademik hedefe ulaşabileceklerine dair inançlarına işaret etmektedir (Pajares, 2012). Yüksek öz yeterliğe sahip öğrenciler yeteneklerinden şüphe duyan öğrencilere göre akademik işlere daha kolay katılmakta, daha çok çalışmakta, çalışmayı daha uzun sürdürmekte ve karşılaştıkları zorluklar karşısında daha az olumsuz duygusal tepkiler göstermekte (Bandura, 1997, Akt. Zimmerman, 2000; Schunk ve Mullen, 2012; Linnenbrink ve Pintrich, 2003), çalışma saatini daha etkili düzenleyebilmekte ve daha etkili problem çözebilmektedir (Usher ve Pajares, 2008).

Pek çok araştırma akademik öz yeterlik ve akademik başarı arasında anlamlı bir ilişkinin olduğunu ortaya koymaktadır (Bandura, Barbaranelli, Caprara ve Pastorelli, 1996; Honicke ve Broadbent, 2016; Pajares ve Miller, 1994; Phan, 2012). Öz yeterlik aynı zamanda öz düzenleme becerilerinin ve stratejilerinin etkili olarak kullanılmasının da önemli bir yordayıcıs1 olarak görülmektedir (Usher ve Pajares, 2008; Diseth, 2011; Zimmerman, Bandura ve Martinez-Pons, 1992). Öz yeterlik inançları, öğrencilerin hedef belirleme, öz izleme, öz değerlendirme ve strateji kullanımı gibi öz düzenleme süreçlerini kullanarak öğrenmelerini motive etmelerini sağlamaktadır (Zimmerman, 2000). Bir beceriyi gösterirken ya da bir işi yerine getirirken öz yeterliği yüksek olan öğrenciler, öğrenme yeteneklerinden 
şüphe duyan öğrencilere göre etkinliklere daha kolay katılmaktadırlar. Daha çok çalışarak zorluklarla karşılaştıklarında üstesinden gelmek için daha çok mücadele etmektedirler. Bilişsel ve bilişüstü stratejileri daha çok ve daha iyi kullandıkları için daha yüksek başarı elde etmektedirler (Pajares, 2002; Schunk ve Zimmerman, 2007). Örneğin, Pintrich ve De Groot (1990), yüksek öz yeterliğe sahip ortaokul öğrencilerinin çeşitli bilişsel ve öz düzenlemeli öğrenme stratejilerini daha çok kullandıklarını bulmuşlardır (Schunk, Pintrich ve Meece, 2010).

Akademik öz yeterlikle ilgili yurt içi araştırmaların çoğunlukla üniversite öğrencilerini ve öğretmen adaylarını (Aydın, 2014; Ekici, 2012; F1rat Durdukoca, 2010; Kandemir, 2014; Oğuz, 2009; Polat, Dilekmen ve Yasul, 2015; Şeker, 2014; Tabancalı ve Çelik, 2013; Yenilmez, 2017; Yılmaz, Gürçay ve Ekici, 2007) kapsadığı dikkat çekmektedir. Bu çalışmaların büyük bir bölümünde öğretmen adaylarının akademik öz yeterlikleri çeşitli değişkenlere göre incelenmiştir. İlköğretim öğrencilerini kapsayan az sayıdaki araştırmaların, ölçek uyarlama çalışmalarını (Öncü, 2012; Telef ve Karaca, 2012); öğrencilerin akademik öz yeterliklerinin yetenek, ortam ve eğitim kalitesine göre karşılaştırılmasını (Demirağ, 2015); bilişüstü farkındalık ve akademik öz yeterlik düzeyleri, motivasyonel inançları ve Temel Eğitimden Ortaöğretime Geçiş Sınavı (TEOG) Türkçe puanlarının incelenmesini (Yıldız, 2015) içermektedir. Bazı araştırmalarda ise öğrencilerin ortaokul ve lise düzeyinde matematik ve fen derslerine yönelik öz yeterlik algıları incelenmiştir (Güngören, 2009; Karaarslan ve Sungur, 2011; Kurbanoğlu ve Takunyac1, 2012). Bununla birlikte ortaokul ve lise öğrencilerinin akademik öz yeterlik algılarını inceleyen çalışmaların sınırlı olduğu dikkat çekmektedir. 
Öğrenci başarısında öz yeterlik gibi güdüsel yapıların yanı sıra bazı kritik beceriler de etkili olmaktadır. Okuduğunu anlama bütün derslerdeki başarıyı etkileyen önemli bir beceridir. Akyol (2006) okuma ve okunandan anlam kurma becerilerini kazandırmanın, insanın hayatını anlamlı hale getirmesine yapılan en büyük katkı olarak eğitim programlarında ve öğretim sürecinde yerini aldığını belirtmektedir. Farklı ülkelerde, farklı eğitim kademelerinde yapılan araştırmalar, okuduğunu anlama gücü ile dil ve edebiyat, matematik ve fen bilimleri başarısı arasında olumlu ilişkinin olduğunu ortaya koymaktadır (Bloom, 2012). Güneş (2007), yapılandırmacı yaklaşıma göre, okumanın sadece anlamak için yapılmadığını, okumanın, sadece yazıların şifresini çözme ve buna anlam ekleme işlemi olmadığını belirtmektedir. Okuma sürecinde okuyucu, amacı çerçevesinde çalışmalar yapmakta ve metindeki bilgilerle ön bilgilerini bütünleştirerek zihninde yapılandırmaktadır. Okuma, bilişsel davranışlarla psikomotor becerilerin ortak çalışmasıyla, yazılı sembollerden anlam çıkarma etkinliğidir (Demirel, 2003).

Okuduğunu anlama alanında okuma sırasında kişinin bilişsel ve güdüsel süreçlerine ilişkin bilişüstü farkındalığının rolü üzerinde durulmaktadır. Araştırmacılar, anlama süreçlerinin farkındalığı ve düzenlenmesinin yetenekli okumanın önemli kritik yönleri olduğunu belirtmektedirler. Farkındalık ve izleme süreçleri literatürde genellikle bilişüstü olarak adlandırılmaktadır. Bilişüstü, okuyucunun okumaya ilişkin bilişsel bilgisi ve metni anlamayı izlerken ve düzenlerken uyguladıkları öz kontrol mekanizmaları olarak düşünülebilir (Mokhtari ve Reichard, 2002).

Bilişüstü, insanların kendi düşünme süreçleriyle ilgili bilgileri (Bruning, Schraw ve Norby, 2014), "düşünmeyi düşünme" ya da öğrenmeyi zihinde kontrol etme (Yıldırım, Doğanay ve Türkoğlu, 2009) olarak tanımlanmaktadır. Açıkgöz (1998), bilişüstünün, kişinin 
kendi bilmesi, bilişsel süreçleri ve bu süreçlerin nasıl işlediği hakkındaki bilgisi ile ilgili olduğunu belirtmektedir. Bilişüstü stratejiler, öğrenme süreci hakkında düşünme, öğrenmeyi planlama, kavramayı ya da anlam çıkarmayı yönetme ve öğretme etkinliğinden sonra kendini değerlendirme stratejilerini içermektedir. Baker ve Brown’a (1984) göre, bilişüstü, bir işi etkili bir şekilde gerçekleştirmek için gerekli olan becerilere, stratejilere ve kaynaklara ilişkin farkındalık ve işin başarılı şekilde tamamlanmasını sağlayacak öz-düzenleme mekanizmalarını kullanma becerisidir (Noushad, 2008). Bilişüstü, bilişin bilgisi ve bilişin düzenlenmesi olmak üzere iki temel kategoriye ayrılmaktadır. Bilişin bilgisi, bireylerin kendi bilişleri veya genel bir kavram olarak biliş hakkında ne bildiklerini ifade eder (Akın, Abacı ve Çetin, 2007). Bilişin düzenlenmesi ise planlama, düzenleme ve değerlendirme olmak üzere üç bileşenden oluşmaktadır (Bruning, Schraw ve Norby, 2014).

Planlama uygun stratejilerin seçilmesini ve performansı etkileyen kaynakların ayarlanmasını içermektedir. Örneğin, okumadan önce tahminde bulunma, stratejileri sıralama, zamanı ayarlama ya da işe başlamadan önce dikkatini yoğunlaştırma. Düzenleme, izleme ve öğrenmeyi kontrol etmek için kendini test etmeyi içerir. Tahminde bulunma, okurken duraklama, eylemleri sıralama ve uygun iyileştirme stratejilerini seçme düzenleme kategorisinde yer almaktadır. Değerlendirme, kişinin öz düzenleme süreçlerini ve öğrenme ürünlerini değerlendirmesinden oluşmaktadır. Örneğin, kişinin hedeflerine ulaşıp ulaşmadığını belirlemesi bu kategoride yer almaktadır (Bruning, Schraw ve Norby, 2014; Schraw, 1998). Yapılan araştırmalar okuduğunu anlamada bilişüstü farkındalığın önemini ve başarılı okuyucuların bilişüstü farkındalığının yüksek olduğunu ortaya koymaktadır (Jacobs ve Paris, 1987; Mokhtari ve Reichard, 2002; Zhang ve Wu, 2009). 
Öğrencilerin bilişüstü okuma stratejilerini kullanmaları sadece okuduğunu anlamada etkili olmamakta, aynı zamanda diğer derslerdeki akademik başarıyı da önemli düzeyde etkilemektedir. Yapılan araştırmalar öğrencilerin bilişüstü okuma stratejilerini kullanma düzeylerinin farklı derslerdeki akademik başarıları üzerinde rol oynayan önemli bir faktör olduğunu göstermektedir (Oluk ve Başöncül, 2009). Ayrıca araştırmalar, yüksek öz yeterliğe sahip öğrencilerin de daha etkili öğrenme stratejileri kullandıklarını ve kendi öğrenme ürünlerini daha fazla izlediklerini ortaya koymaktadır (Noushad, 2008). Ortaokul öğrencilerinin akademik öz yeterlik algılarının ve okuma stratejileri bilişüstü farkındalıklarının çeşitli değişkenler açısından incelenmesinin alanyazına, öğretim programlarının geliştirilmesine ve öğretim süreçlerinin yapılandırılmasına katkı sağlayacağı düşünülmektedir.

$\mathrm{Bu}$ araştırmanın amacı, ortaokul öğrencilerinin akademik öz yeterlik algılarının ve okuma stratejileri bilişüstü farkındalıklarının sınıf düzeyine, cinsiyete ve anne baba eğitim durumuna göre faklılık gösterip göstermediğini ve akademik öz yeterlik algıları ile okuma stratejileri bilişüstü farkındalıkları arasındaki ilişkiyi saptamaktır. Böylelikle ortaokul öğrencilerinin akademik öz yeterlik algıları ve okuma stratejileri bilişüstü farkındalıklarına ilişkin var olan durumun saptanmasının, bu özelliklerin geliştirilmesi için alınacak önlem ve uygulamalarda yol gösterici olacağı düşünülmektedir. Ayrıca bu araştırmadan elde edilen bulgular, konuyla ilgili yapılacak çalışmalarda katkı sağlayacaktır. Bu amaç doğrultusunda aşă̆ıdaki sorulara yanıt aranmaktadır:

$\checkmark$ Ortaokul öğrencilerinin akademik öz yeterlik algıları sınıf düzeyine, cinsiyete, anne baba eğitim durumuna göre anlamlı farklılık göstermekte midir? 
$\checkmark$ Ortaokul öğrencilerinin okuma stratejileri bilişüstü farkındalıkları sınıf düzeyine, cinsiyete, anne baba eğitim durumuna göre anlamlı farklılık göstermekte midir?

$\checkmark$ Ortaokul öğrencilerinin akademik öz yeterlik algıları ile okuma stratejileri bilişüstü farkındalıkları arasında anlamlı bir ilişki bulunmakta mıdır?

\section{Yöntem}

\section{Araştırma Modeli}

Araştırmada iki ve daha çok sayıda değişken arasında birlikte değişimin varlığı veya derecesini araştıran genel tarama modellerinden korelasyonel tarama modeli (Karasar, 2004) kullanılmıştır.

\section{Evren ve Örneklem}

Bu araştırma Sivas ili Merkez ilçesinde 2014-2015 öğretim y1lı güz döneminde yapılmıştır. Basit seçkisiz örnekleme yönteminin kullanıldığı bu araştırmaya 539’u kız, 520'si erkek toplam 1059 öğrenci katılmıştır. Araştırmaya katılan tüm öğrenciler devlet okullarında öğrenim görmektedirler. Sivas merkezinde bulunan okullarda öğrenim gören 23.577ortaokul öğrencisinden 0.05 anlamlılık düzeyinde $\mathrm{d}= \pm 0.03$ örnekleme hatası (Yazıcıoğlu ve Erdoğan, 2014) temel alınarak 1059 öğrenci örnekleme alınmıştır. Tablo 1'de örnekleme ilişkin betimsel istatistikler sunulmaktadır.

Tablo 1.

Örnekleme İlişkin Betimsel İstatistikler

\begin{tabular}{llll}
\hline Değişkenler & & Frekans (f) & Yüzde (\%) \\
\hline Cinsiyet & Kiz & 539 & 50.9 \\
& Erkek & 520 & 49.1 \\
\hline \multirow{3}{*}{ Sinıf } & 5. Sinıf & 274 & 25.9 \\
& 6. Sinıf & 217 & 20.5 \\
& 7. Sinıf & 253 & 23.9 \\
& 8. Sinıf & 315 & 29.7 \\
\hline
\end{tabular}




\begin{tabular}{llll}
\hline & İlkokul & 318 & 30.1 \\
Anne Eğitim & Ortaokul & 368 & 34.8 \\
Durumu & Lise & 261 & 24.7 \\
& Üniversite & 110 & 10.4 \\
\hline & İlkokul & 119 & 11.3 \\
Baba Eğitim & Ortaokul & 225 & 21.3 \\
Durumu & Lise & 442 & 41.8 \\
& Üniversite & 270 & 25.6 \\
\hline
\end{tabular}

Tablo 1 incelendiğinde örneklemin hem cinsiyet $(\mathrm{k} 1 \mathrm{z}=\% 50.9 \mathrm{~N}=539$, erkek=\%49.1 $N=520$ ) hem de sinıf düzeyi (5. Sinıf=\%25.9 N=274, 6. Sınıf=\%20.5 N=217, 7. Sınıf=\%23.9 $\mathrm{N}=253$, 8. Sınıf=\%29.7 N=315) açısından dengeli bir dağılım gösterdiği görülmektedir.

\section{Veri Toplama Aracı}

Bu çalışma kapsamında kullanılan veri toplama aracı üç bölümden oluşmaktadır. Birinci bölüm demografik soruları kapsamaktadır. İkinci bölüm Çocuklar İçin Öz Yeterlik Ölçeği’nin Akademik Öz Yeterlik alt ölçeğinden oluşmakta, üçüncü bölümde ise Okuma Stratejileri Bilişsel Farkındalık Ölçeği yer almaktadır.

\section{Çocuklar için öz-yeterlik ölçeği/akademik öz yeterlik alt ölçeği.}

Çocuklar İçin Öz-yeterlik Ölçeği, Muris (2001) tarafından 12-19 yaşları arasındaki ergenlerin sosyal, akademik ve duygusal öz-yeterliklerini ölçmek amacı ile geliştirilmiştir. Ölçeğin Türkçeye uyarlama çalışması Telef (2011) tarafından yapılmıştır. Çocuklar için özyeterlik ölçeği, akademik öz yeterlik, sosyal öz yeterlik ve duygusal öz yeterlik olmak üzere üç faktörlü bir yapıya sahiptir ve toplam 21 maddeden oluşmaktadır. Ölçeğin iç tutarlık katsayıları incelendiğinde ölçeğin geneli için .86, alt boyutlarından akademik öz-yeterlik için .84, sosyal öz-yeterlik için .64, duygusal öz-yeterlik için .78 olarak hesaplanmıştır. Bu çalışmada Çocuklar İçin Öz-yeterlik Ölçeği'nin 7 maddelik Akademik Öz Yeterlik alt ölçeği kullanılmıştır ve bu araştırmada alt ölçeğe ilişkin Cronbach Alpha güvenirlik katsayısı .81 
olarak hesaplanmıştır. Çocuklar İçin Öz-yeterlik Ölçeği beşli Likert tipi $(1=$ hiç ve $5=$ çok iyi) bir ölçektir.

\section{Okuma stratejileri bilişsel farkındalık ölçeği.}

Okuma Stratejileri Bilişsel Farkındalık Ölçeği Karatay (2009) tarafından geliştirilmiştir. Ölçek, kişilerin okuduğunu anlama stratejileri ile ilgili bilişsel farkındalık düzeyini ölçmeye yönelik 32 maddeden oluşan, üç boyutlu bir ölçektir. Ölçekte okumayı planlama stratejilerine yönelik 9 madde, düzenleme stratejilerine yönelik 14 madde ve değerlendirme stratejilerine yönelik 9 madde bulunmaktadır. Ölçeğin, yapılan uygulamalardan elde edilen Cronbach Alpha güvenirlik katsayıları, planlama stratejileri için .68; düzenleme stratejileri için .84; değerlendirme stratejileri için .80 ve ölçeğin toplamı için .92 olarak bulunmuştur. Bu araştırmada Cronbach Alpha güvenirlik katsayısı planlama için .77, düzenleme için .82, değerlendirme için .82, ölçeğin toplamı için .92 olarak hesaplanmıştır.

\section{Verilerin Analizi}

Puanların normal dağılım özelliği Kolmogorov-Smirnov (K-S) Testi ile incelenmiștir. Kolmogorov-Smirnov Testi sonucuna $(\mathrm{p}<.05)$ göre normal dağılım varsayımı karşılanmadığı için ortaokul öğrencilerinin akademik öz yeterlik algıları ve okuma stratejileri bilişüstü farkındalıklarının cinsiyet, sınıf düzeyi ve anne baba eğitim durumuna göre farklılaşıp farklılaşmadığı Kruskal Wallis Testi ve Mann Whitney U Testi ile belirlenmiştir (Büyüköztürk, 2010; Kalaycı, 2010). Akademik öz yeterlik algısı ve okuma stratejileri bilişüstü farkındalık arasındaki ilişki Pearson korelasyon katsayısı ile incelenmiştir.

\section{Bulgular}

$\mathrm{Bu}$ bölümde araştırma verilerinin analizi sonucu ulaşılan bulgular yer almaktadır. İlk olarak ölçeklere ilişkin betimsel istatistikler incelenmiş ve tablo 2'de sunulmaktadır. 
Tablo 2

Ölçeklere İlişkin Betimsel İstatistikler

\begin{tabular}{lcllcc}
\hline Ölçekler & $\mathrm{N}$ & $\begin{array}{l}\text { En Düşük } \\
\text { Puan }\end{array}$ & $\begin{array}{l}\text { En Yüksek } \\
\text { Puan }\end{array}$ & $\overline{\boldsymbol{X}}$ & Ss \\
\hline Akademik Öz Yeterlik & 1059 & 9.00 & 35.00 & 28.11 & 5.11 \\
Planlama & 1059 & 9.00 & 45.00 & 34.20 & 6.80 \\
$\begin{array}{l}\text { Düzenleme } \\
\text { Değerlendirme }\end{array}$ & 1059 & 18.00 & 70.00 & 53.34 & 9.82 \\
& 1059 & 9.00 & 45.00 & 32.84 & 7.56 \\
\hline
\end{tabular}

Ortaokul öğrencilerinin akademik öz yeterlik ölçeğinden aldıkları en düşük puanın 9.00, en yüksek puanın 35.00 olduğu görülmektedir. Aritmetik ortalama 28.11, standart sapma 5.11'dir. Ortaokul öğrencilerinin okuma stratejileri bilişüstü farkındalıkları, planlama alt boyutunda aldıkları en düşük puan 9.00, en yüksek puan 45.00; düzenleme alt boyutunda en düşük puan 18.00, en yüksek puan 70.00; değerlendirme alt boyutunda en düşük puan 9.00, en yüksek puan 45.00'tir. Aritmetik ortalama planlama alt boyutu için 34.20; düzenleme alt boyutu için 53.34; değerlendirme alt boyutu için 32.84 olarak bulunmuştur. Standart sapma ise planlama alt boyutu için 6.80; düzenleme alt boyutu için 9.82; değerlendirme alt boyutu için 7.56 olarak hesaplanmıştır.

\section{Ortaokul Öğrencilerinin Akademik Öz Yeterlik Algılarına İlişkin Bulgular}

Ortaokul öğrencilerinin sınıf düzeyine göre akademik öz yeterlik algıları arasında anlamlı bir fark olup olmadığı Kruskal Wallis Testi ile test edilmiş ve sonuçları Tablo 2'de gösterilmiştir. Tablo 2

Ortaokul Öğrencilerinin Akademik Öz Yeterlik Algllarının Sınıf Düzeyine Göre Kruskal Wallis Testi Sonuçları

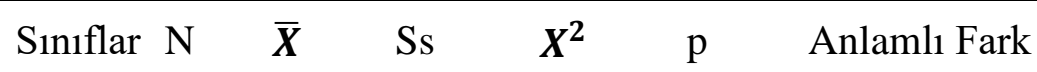




\begin{tabular}{llllllll}
\hline & 5.Sinıf & 274 & 30.34 & 4.12 & & & \\
Akademik Öz & 6.Sınıf & 217 & 27.54 & 4.72 & 79.315 & 0.00 & $* 5-6, * 5-7$, \\
Yeterlik & 7.Sinıf & 253 & 27.07 & 5.56 & & & \\
& 8.Sinıf & 315 & 27.41 & 5.22 & & & \\
\hline $\mathrm{p}<.05$ & & & & & &
\end{tabular}

Tablo 2'de ortaokul öğrencilerinin akademik öz yeterlik algılarının sınıf düzeyine göre ortalamaları incelendiğinde, 5. Sınıf öğrencilerinin $(\bar{X}=30.34)$ en yüksek ortalamaya sahip oldukları görülmektedir. Ortaokul öğrencilerinin akademik öz yeterlik algıları sınıf düzeyine göre $\left(X^{2}=79.315 ; \mathrm{p}<.05\right)$ anlamlı farklılık göstermektedir. Anlamlı farklılığın hangi gruplar arasında olduğunu saptamak için yapılan Mann Whitney U Testi sonucuna göre farklılık 5-6, 5-7 ve 5-8. sınıflar arasındadır. Ortaokul öğrencilerinin cinsiyete göre akademik öz yeterlik algıları arasında anlamlı bir fark olup olmadığı Mann Whitney $U$ testi ile test edilmiş ve sonuçları Tablo 3’te gösterilmiştir.

Tablo 3

Ortaokul Öğrencilerinin Akademik Öz Yeterlik Algllarının Cinsiyete Göre Mann Whitney U Testi Sonuçları

\begin{tabular}{lllllll}
\hline & Cinsiyet & $\mathrm{N}$ & $\overline{\boldsymbol{X}}$ & $\mathrm{Ss}$ & $\boldsymbol{U}$ & $\mathrm{p}$ \\
\hline Akademik Öz & K1z & 539 & 28.51 & 5.01 & \multirow{2}{*}{$127052 . *$} & .008 \\
Yeterlik & Erkek & 520 & 27.70 & 5.19 & & \\
\hline${ }^{*} \mathrm{p}<.05$ & & & & & &
\end{tabular}

Tablo 3'e göre ortaokul öğrencilerinin akademik öz yeterlik algıları cinsiyete göre anlamlı farklılık $(\mathrm{U}=127052.00, \mathrm{p}<.05)$ göstermektedir. Bu farkın kız öğrenciler lehine (Kız: $\bar{X}=28.51$; Erkek: $\bar{X}=27.70$ ) olduğu görülmektedir.

Tablo 4

Ortaokul Öğrencilerinin Akademik Öz Yeterlik Algılarının Anne Eğitim Durumuna Göre Kruskal Wallis Testi Sonuçları

\begin{tabular}{lllllll}
$\begin{array}{l}\text { Anne } \\
\text { Eğitim Durumu }\end{array}$ & N & $\bar{X}$ & Ss & $\boldsymbol{X}^{\mathbf{2}}$ & p & $\begin{array}{l}\text { Anlamli } \\
\text { Fark }\end{array}$ \\
\hline
\end{tabular}




\begin{tabular}{llllllll}
\hline & İlkokul & 318 & 27.74 & 5.19 & & & * İlkokul- \\
Akademik & Ortaokul & 368 & 27.90 & 5.13 & $9.536^{*}$ & .023 & Üniversite, \\
Öz Yeterlik & Lise & 261 & 28.33 & 5.20 & & & *Ortaokul- \\
& Üniversite & 110 & 29.38 & 4.43 & & & Üniversite \\
\hline
\end{tabular}

$* \mathrm{p}<0.05$

Tablo 4 incelendiğinde ortaokul öğrencilerinin akademik öz yeterlik algılarının anne eğitim durumuna göre anlamlı farklılık gösterdiği $\left(X^{2}=9.536, \mathrm{p}<0.05\right)$ saptanmaktadır. $\mathrm{Bu}$ farklılığın hangi gruplar arasında olduğunu saptamak amacıyla yapılan Mann Whitney U Testi sonucuna göre farkl111k, ilkokul $(\bar{X}=27.74, \mathrm{Ss}=5.19)$ ile üniversite $(\bar{X}=29.38, \mathrm{Ss}=4.43)$ ve ortaokul $(\bar{X}=27.90$, Ss=5.13) ile üniversite $(\bar{X}=29.38$, Ss=4.43 $)$ arasındadır. Grupların ortalamaları incelendiğinde ilkokul en düşük $(\bar{X}=27.74$, Ss=5.19), üniversite $(\bar{X}=29.38$, $\mathrm{Ss}=4.43)$ en yüksek ortalamaya sahiptir.

Tablo 5

Ortaokul Öğrencilerinin Akademik Öz Yeterlik Algılarının Baba Ĕ̆itim Durumuna Göre Kruskal Wallis Testi Sonuçları

\begin{tabular}{llllllll}
\hline & $\begin{array}{l}\text { Baba Eğitim } \\
\text { Durumu }\end{array}$ & $\mathrm{N}$ & $\bar{X}$ & $\mathrm{Ss}$ & $X^{2}$ & $\mathrm{p}$ & Anlamlı Fark \\
\hline Akademik & İlkokul & 119 & 27.05 & 5.59 & & & * İlkokul- Üniversite, \\
Öz & Ortaokul & 225 & 27.72 & 5.02 & 13.440 & $.004 *$ & *Ortaokul- \\
Yeterlik & Lise & 442 & 28.10 & 5.12 & & & Üniversite, *Lise- \\
& Üniversite & 270 & 28.93 & 4.85 & & & Üniversite \\
\hline
\end{tabular}
* $\mathrm{p}<0.05$

Tablo 5'te ortaokul öğrencilerinin akademik öz yeterlik algılarının baba eğitim durumuna göre anlamlı farklılık $\left(X^{2}=13.440, \mathrm{p}<0.05\right)$ gösterdiği görülmektedir. Farklılığın hangi gruplar arasında olduğunu saptamak için yapılan Mann Whitney U Testi sonucuna göre farklılık, ilkokul $(\bar{X}=27.05, \mathrm{Ss}=5.59)$, ortaokul $(\bar{X}=27.72, \mathrm{Ss}=5.02)$, lise $(\bar{X}=28.10, \mathrm{Ss}=5.12)$ ile üniversite $(\bar{X}=28.93, \mathrm{Ss}=4.85)$ arasındadır. 


\section{Ortaokul Öğrencilerinin Okuma Stratejileri Bilişüstü Farkındalıklarına İlişkin}

\section{Bulgular}

Tablo 6

Ortaokul Öğrencilerinin Okuma Stratejileri Bilişüstü Farkındalıklarının Sınıf Düzeyine Göre Kruskal Wallis Testi Sonuçları

\begin{tabular}{|c|c|c|c|c|c|c|c|}
\hline $\begin{array}{l}\text { Okuma Stratejileri } \\
\text { Bilişüstü Farkındalık }\end{array}$ & Sinıflar & $\mathrm{N}$ & $\bar{X}$ & Ss & $X^{2}$ & $\mathrm{p}$ & Anlamlı Fark \\
\hline \multirow{4}{*}{ Planlama } & 5.Sinif & 274 & 36.47 & 6.40 & \multirow{4}{*}{50.195} & \multirow{4}{*}{$0.000 *$} & \multirow{4}{*}{$\begin{array}{l}* 5-6, * 5-7 \\
* 5-8\end{array}$} \\
\hline & 6.Sinıf & 217 & 33.74 & 6.88 & & & \\
\hline & 7.Sinıf & 253 & 33.07 & 6.59 & & & \\
\hline & 8.Sinıf & 315 & 33.45 & 6.83 & & & \\
\hline \multirow{4}{*}{ Düzenleme } & 5.Sinif & 274 & 57.24 & 8.94 & \multirow{4}{*}{69.469} & \multirow{4}{*}{$0.000^{*}$} & \multirow{4}{*}{$\begin{array}{l}* 5-6, * 5-7, \\
* 5-8,\end{array}$} \\
\hline & 6.Sinif & 217 & 52.48 & 9.35 & & & \\
\hline & 7.Sinıf & 253 & 51.30 & 9.28 & & & \\
\hline & 8.Sinıf & 315 & 52.17 & 10.37 & & & \\
\hline \multirow{4}{*}{ Değerlendirme } & 5.Sinif & 274 & 35.33 & 7.30 & \multirow{4}{*}{48.141} & \multirow{4}{*}{$0.000^{*}$} & \multirow{4}{*}{$\begin{array}{l}* 5-6, * 5-7, \\
* 5-8,\end{array}$} \\
\hline & 6.Sinif & 217 & 32.64 & 7.10 & & & \\
\hline & 7.Sinif & 253 & 31.37 & 7.36 & & & \\
\hline & 8.Sinıf & 315 & 31.99 & 7.75 & & & \\
\hline
\end{tabular}

Tablo 6'da ortaokul öğrencilerinin okuma stratejileri bilişüstü farkındalıkları planlama $\left(X^{2}=50.195, \mathrm{p}<0.05\right)$, düzenleme $\left(X^{2}=69.469, \mathrm{p}<0.05\right)$ ve değerlendirme $\left(X^{2}=48.141\right.$, p<0.05) alt boyutlarında sınıf düzeyine göre anlamlı farklılık göstermektedir. Farklılığın hangi sınıflar arasında olduğunu belirlemek amacıyla yapılan Mann Whitney U Testi sonucuna göre, planlama alt boyutundaki farklılığın 5. Sınıf $(\bar{X}=36.47$, Ss=6.40) ile 6 . $(\bar{X}=33.74, \mathrm{Ss}=6.88), 7 . \quad(\bar{X}=33.07, \mathrm{Ss}=6.59) \quad$ ve $8 .(\bar{X}=33.45, \mathrm{Ss}=6.83) \quad$ siniflar arasinda olduğu görülmektedir. Düzenleme alt boyutunda farklılık 5. sinıf $(\bar{X}=57.24$, Ss=8.94) ile 6 . $(\bar{X}=52.48, \mathrm{Ss}=9.35), 7 .(\bar{X}=51.30, \mathrm{Ss}=9.28)$ ve $8 .(\bar{X}=52.17, \mathrm{Ss}=10.37)$ sinıflar arasindadir. Değerlendirme boyutunda 5. sinıf $(\bar{X}=35.33$, Ss=7.30) ile 6. $(\bar{X}=32.64, \quad \mathrm{Ss}=7.10), 7$. 
$(\bar{X}=31.37, \quad$ Ss=7.36 $)$ ve $8 . \quad(\bar{X}=31.99, \quad$ Ss=7.75 $) \quad$ siniflar arasinda anlamlı farklılık bulunmaktadır.

Tablo 7

Ortaokul Öğrencilerinin Okuma Stratejileri Bilişüstü Farkındalıklarının Cinsiyete Göre Mann Whitney U Testi Sonuçları

\begin{tabular}{lllcccl}
\hline OSBF & Cinsiyet & $\mathrm{N}$ & $\bar{X}$ & $\mathrm{Ss}$ & $\mathrm{U}$ & $\mathrm{P}$ \\
\hline \multirow{2}{*}{ Planlama } & K1z & 539 & 35.04 & 6.63 & $118529.500^{*}$ & .000 \\
& Erkek & 520 & 33.33 & 6.88 & & \\
Düzenleme & K1z & 539 & 54.74 & 9.54 & $115711.500^{*}$ & .000 \\
& Erkek & 520 & 51.88 & 9.90 & & \\
Değerlendirme & K1z & 539 & 33.83 & 7.38 & $117409.500^{*}$ & .000 \\
& Erkek & 520 & 31.81 & 7.61 & & \\
\hline
\end{tabular}
*p<0.05

Tablo 7'ye göre ortaokul öğrencilerinin okuma stratejileri bilişüstü farkındalıkları planlama $\quad(\mathrm{U}=118529.500, \quad \mathrm{p}<.05 ; \quad \mathrm{K} 1 \mathrm{z}: \quad \bar{X}=35.04 ; \quad$ Erkek: $\bar{X}=33.33), \quad$ düzenleme $(\mathrm{U}=115711.500, \mathrm{p}<.05$; K1z: $\bar{X}=54.74$; Erkek: $\bar{X}=51.88)$ ve değerlendirme $(\mathrm{U}=117409.500$, p<.05; Kız: $\bar{X}=33.83$; Erkek: $\bar{X}=31.81$ ) alt boyutlarında cinsiyete göre anlamlı farklılık göstermektedir. $\mathrm{Bu}$ farklılı̆̆ın bütün alt boyutlarda kız öğrenciler lehine olduğu görülmektedir.

Tablo 8

Ortaokul Öğrencilerinin Okuma Stratejileri Bilişüstü Farkındalıklarının Anne Eğitim Durumuna Göre Kruskal Wallis Testi Sonuçları

\begin{tabular}{lllllll}
\hline OSBF & $\begin{array}{l}\text { Anne Eğitim } \\
\text { Durumu }\end{array}$ & $\mathrm{N}$ & $\overline{\mathrm{X}}$ & $\mathrm{Ss}$ & $X^{2}$ & $\mathrm{p}$ \\
\hline \multirow{4}{*}{ Planlama } & İlkokul & 318 & 33.64 & 6.55 & 6.956 & .073 \\
& Ortaokul & 368 & 34.23 & 6.86 & & \\
& Lise & 261 & 34.39 & 6.95 & & \\
Üniversite & 110 & 35.26 & 6.93 & & \\
Düzenleme & İlkokul & 318 & 53.19 & 9.44 & 1.154 & .764 \\
& Ortaokul & 368 & 53.43 & 10.09 & & \\
& Lise & 261 & 53.21 & 9.74 & &
\end{tabular}




\begin{tabular}{lllllll} 
& Üniversite & 110 & 53.80 & 10.17 & & \\
& İlkokul & 318 & 32.14 & 7.22 & 7.145 & .067 \\
Değerlendirme & Ortaokul & 368 & 33.03 & 7.43 & & \\
& Lise & 261 & 33.20 & 7.48 & & \\
& Üniversite & 110 & 33.46 & 8.85 & & \\
\hline
\end{tabular}

$* \mathrm{p}<0.05$

Tablo 8'e göre ortaokul öğrencilerinin okuma stratejileri bilişüstü farkındalıkları planlama $\left(X^{2}=6.956, \mathrm{p}>0.05\right)$, düzenleme $\left(X^{2}=1.154, \mathrm{p}>0.05\right)$ ve değerlendirme $\left(X^{2}=7.145\right.$, p>0.05) alt boyutlarında anne eğitim durumuna göre anlamlı farklılık göstermemektedir.

Tablo 9

Ortaokul Öğrencilerinin Okuma Stratejileri Bilişüstü Farkındalıklarının Baba Ĕ̆itim Durumuna Göre Kruskal Wallis Testi Sonuçları

\begin{tabular}{lllllll}
\hline & Baba Ĕgitim & $\mathrm{N}$ & $\overline{\mathrm{X}}$ & $\mathrm{Ss}$ & $X^{2}$ & $\mathrm{p}$ \\
& Durumu & & & & & \\
\hline \multirow{4}{*}{ Planlama } & İlkokul & 119 & 33.25 & 6.44 & 5.828 & .120 \\
& Ortaokul & 225 & 34.13 & 6.87 & & \\
& Lise & 442 & 34.12 & 6.93 & & \\
& Üniversite & 270 & 34.84 & 6.65 & & \\
\hline \multirow{5}{*}{ Düzenleme } & İlkokul & 119 & 52.98 & 9.42 & 1.314 & .726 \\
& Ortaokul & 225 & 53.34 & 9.36 & & \\
& Lise & 442 & 53.13 & 10.11 & & \\
& Üniversite & 270 & 53.83 & 9.86 & & \\
\hline \multirow{5}{*}{ Değerlendirme } & İlkokul & 119 & 31.61 & 7.26 & 5.584 & .134 \\
& Ortaokul & 225 & 32.92 & 7.36 & & \\
& Lise & 442 & 32.83 & 7.66 & & \\
\hline
\end{tabular}

$* \mathrm{p}<0.05$

Tablo 9 incelendiğinde ortaokul öğrencilerinin okuma stratejileri bilişüstü farkındalıkları, planlama $\left(X^{2}=5.828, \quad \mathrm{p}>0.05\right)$, düzenleme $\left(X^{2}=1.314, \quad \mathrm{p}>0.05\right) \quad$ ve değerlendirme $\left(X^{2}=5.584, \mathrm{p}>0.05\right)$ alt boyutlarında baba eğitim durumuna göre anlamlı farklılık olmadığı görülmektedir.

Ortaokul Öğrencilerinin Akademik Öz Yeterlik Algıları ile Okuma Stratejileri Bilişüstü Farkındalıkları Arasındaki İlişkiye İlişkin Bulgular

Tablo 10 
Ortaokul Öğrencilerin Akademik Öz Yeterlik Alglları ile Okuma Stratejileri Bilişüstü Farkındalıkları Arasındaki İlişkiye İlişkin Korelasyon

\begin{tabular}{lcccc}
\hline & AÖY & P & DÜ & DE \\
\hline Akademik Öz Yeterlik & 1.00 & $.55^{* *}$ & $.56^{* * *}$ & $.53^{* *}$ \\
Planlama & & 1.00 & $.77^{* *}$ & $.78^{* *}$ \\
Düzenleme & & & 1.00 & $.79^{* *}$ \\
Değerlendirme & & & & 1.00 \\
\hline
\end{tabular}

$* * \mathrm{p}<0.01$

Tablo 10’a göre ortaokul öğrencilerinin akademik öz yeterlik algıları ile okuma stratejileri bilişüstü farkındalıkları planlama $(\mathrm{r}=.55)$, düzenleme $(\mathrm{r}=.56)$ ve değerlendirme $(\mathrm{r}=.53)$ alt boyutları arasında pozitif yönde orta düzeyde ilişki bulunmaktadır.

\section{Sonuç, Tartışma ve Öneriler}

$\mathrm{Bu}$ çalışmada ortaokul öğrencilerinin akademik öz yeterlik algıları ve okuma stratejileri bilişüstü farkındalıkları sınıf düzeyine, cinsiyete ve anne baba eğitim durumuna göre incelenmiştir. Ortaokul öğrencilerinin akademik öz yeterlik algılarında, sınıf düzeyine göre 5. sinıflar ile 6, 7 ve 8. sinıflar arasında 5. sinıf lehine anlamlı farklılığın olduğu görülmektedir. $\mathrm{Bu}$ sonucun, ergenlikle birlikte öz inançlarda, öz yeterlik ve öğrenmeye verilen değer gibi güdüsel-bilişüstü bileşenlerde düşüş görülmesiyle ilişkili olduğu düşünülmektedir. Nicholls'un (1984) belirttiği gibi, çocuklar okula kendi yeteneklerine ilişkin olumlu bakış açısıyla başlamaktalar, ancak 11 ve 12 yaşlarından itibaren yeteneklerine ilişkin öz algıda belirgin bir düşüş olmaktadır (Akt. Noushad, 2008). Schunk ve Pajares (2002), ilkokuldan ortaokula geçiş gibi süreçlerin bazı değişiklikleri beraberinde getirdiği için öğrencilerin akademik öz yeterliklerinde düşüşe neden olduğunu belirtmektedirler. Ortaokul 7. sınıftan itibaren akademik öz yeterlikte düşüş görülmekte, bazı araştırmalar ise düşüşün daha erken sınıflarda başladığını göstermektedir (Schunk ve Pajares, 2002). Çalışmada, öğrencilerin okuma stratejileri bilişüstü farkındalık düzeyleri ile ilgili ulaşılan sonuçlar da 
benzerlik göstermektedir. Ortaokul öğrencilerinin okuma stratejileri bilişüstü farkındalıkları planlama, düzenleme ve değerlendirme alt boyutlarında sınıf düzeylerine göre 5. sinıflar ile 6 , 7 ve 8. sinıflar arasında 5. sinıf lehine anlamlı farklılık göstermektedir. Bulut (2016) tarafından yapılan bir çalışmada da 5. sınıf öğrencilerinin okuma stratejileri bilişüstü farkındalıkları 6, 7 ve 8. sınıf öğrencilerine göre anlamlı düzeyde yüksek bulunmuştur. Koç ve Karabağ'ın (2013) yaptıkları araştırmada ilköğretim ikinci kademe öğrencilerinin bilişüstü yetileri düzenleme alt boyutunda ve toplam puanda 6 . sinıflar ile 7 ve 8 . sinıflar arasında 6 . sınıfların lehine anlamlı farklılık bulunmuştur. Bu sonuç Atay'ın (2014) yaptığ çalışma sonuçlarıyla da örtüşmektedir. Ayrıca Evran ve Yurdabakan (2013) yaptıkları çalışmada sınıf düzeyine göre anlamlı farkl1lıklar bulunduğu belirlenmiştir. Bu bulgular bilişüstünün yaşla birlikte geliştiği ve yaş ilerledikçe arttığı görüşü ile tutarsızlık göstermektedir. Noushad (2008) 11 -12 yaşlarındaki çocukların daha küçük çocuklara göre kendi performanslarına ilişkin yansıtma ve bilişsel becerileri değerlendirme ya da kontrol etmede daha iyi olduklarını aktarmaktadır. Ancak ergenlikle birlikte güdüsel-bilişüstü bileşenlerde düşüş görülmektedir. Ayrıca benlik saygısı ergenlikte dalgalanmalar göstermekte, değişikliğe uğramakta ve ortaokul ve liseye geçişte buluğ başlangıcında en düşük düzeydedir (Slavin, 2012). Bu gelişimsel özelliklerin ortaokul öğrencilerinin akademik öz yeterlik inançları ve okuma stratejileri bilişüstü farkındalıkları üzerinde etkili olduğu düşünülmektedir.

Araştırma bulgularına göre ortaokul öğrencilerinin akademik öz yeterlik algıları cinsiyete göre kız öğrenciler lehine anlamlı farklılık göstermektedir. Cinsiyet ve öz yeterlik arasındaki ilişkiyi inceleyen araştırmaların çoğunluğu erkeklerin matematik, fen ve teknoloji alanlarında kadınlara göre daha öz güvenli olduklarını ortaya koymaktadır. Kadınlar dil sanatlarında daha başarılı olmalarına rağmen bu alanda kadın ve erkekler benzer güven 
sergilemektedirler (Schunk ve Pajares, 2002). Akbaş ve Çelikkaleli (2006), Oğuz (2012) tarafından üniversite öğrencileri düzeyinde yapılan çalışmalarda cinsiyete göre anlamlı farklılık bulunamamıştır. Fırat Durdukaca'nın (2010) yaptığı araştırmada ise erkek öğrenciler lehine farklılık bulunmuştur. Görüldüğü gibi akademik öz yeterlik algısının cinsiyete göre incelendiği araştırma bulguları farklılık göstermektedir.

Araştırmada ortaokul öğrencilerinin akademik öz yeterlik algılarının anne ve baba eğitim durumuna göre anlamlı farklılık gösterdiği saptanmıştır. Gruplarda ilkokul düzeyinin en düşük, üniversite düzeyinin ise en yüksek ortalamaya sahip olduğu görülmektedir. Bu farklılığın üniversite mezunu anneler ile ilk ve ortaokul mezunu anneler arasında; üniversite mezunu babalar ile ilk, ortaokul ve lise mezunu babalar arasında olduğu belirlenmiştir. Schunk ve Pajares (2002), Çocukların merakını uyaran ve öğrenme deneyimlerine izin veren ortamlar sunan ebeveynlerin öz yeterliğin gelişimini olumlu yönde etkilediklerini belirtmektedirler. Çocukların merakını uyandıracak ilginç etkinlikler ve çocukların üstesinden gelebileceği güçlükler sunan zengin ortamlar, çocukları etkinliklere motive etmekte ve yeni bilgi ve beceriler öğrenmelerini sağlamaktadır (Meece, 1997, Akt. Schunk ve Pajares, 2002). Eğitim düzeyi yüksek olan anne babaların, çocukların öğrenme ve akademik gelişimlerini destekleyen ortamlar sunma ve model olma bakımından daha avantajlı oldukları söylenebilir.

Yapılan çalışmada okuma stratejileri ve bilişüstü farkındalıkları planlama, düzenleme ve değerlendirme alt boyutlarında k1z öğrencilerin lehine anlamlı farklılık olduğu belirlenmiştir. Karatay (2010), Bağçeci, Döş ve Sarıca (2011), Kaya ve Fırat (2011), Akın ve Çeçen (2014), Kana (2014), Bulut (2016) ortaokul öğrencileri ile yaptıkları çalışmada, kız öğrencilerin okuma stratejileri üstbilişsel farkındalık düzeylerinin erkek öğrencilere göre 
anlamlı farklılık gösterdiğini saptamışlardır. Evran ve Yurdabakan (2013), Koç ve Karabağ’’n (2013) yaptıkları çalışmada bilişüstü yetide kız öğrenciler lehine anlamlı farklılık bulunmuştur. Ateş (2013), Tunca ve Alkın-Şahin (2014) üniversite öğrencileri ile yaptıkları çalışmalarda da benzer sonuçlara ulaşmışlardır.

Araştırma bulgularına göre ortaokul öğrencilerinin okuma stratejileri bilişüstü farkındalıkları anne ve baba eğitim durumuna göre anlamlı farklılık göstermemektedir. Bu sonuç bazı çalışmaların sonuçları ile tutarsızlık göstermektedir. Örneğin, Kaya ve Fırat'ın (2011) yaptıkları çalışmada anne ve baba öğrenim düzeyi yükseldikçe öğrencilerin bilişüstü farkındalıklarının arttığı sonucuna ulaşılmıştır. Kana (2014) tarafından yapılan çalışmada da ailesinde her gün okuma alışkanlığı olan öğrencilerin okurken daha stratejik oldukları saptanmıştır. Araştırmada bu bulgu beklenmeyen bir bulgudur, çünkü anne ve babaların eğitim düzeyleri arttıkça çocuklarına öğrenmeyle ilgili daha zengin ortamlar sunabilecekleri düşünülmektedir. Bu konunun farklı örneklemler üzerinde araştırılmasının yararlı olacağı düşünülmektedir.

Araştırmada ortaokul öğrencilerinin akademik öz yeterlik algıları ile okuma stratejileri bilişüstü farkındalıkları arasında orta düzeyde pozitif yönde ilişki saptanmıştır. Öz yeterliği yüksek öğrencilerin daha başarılı, akademik zorluklar karşısında daha sabırlı ve 1srarlı oldukları ve daha çok çaba gösterdikleri belirtilmektedir (Schunk ve Pajares, 2002). Ayrıca öz yeterlik ile bilişsel strateji kullanımı ve öz düzenleme arasında olumlu ilişki bulunmaktadır (Pintrich ve De Groot, 1990). Tavakolizadeh, Tabari ve Akbari (2015) tarafinda lise öğrencileri ile Hermita ve Thamrin (2015) tarafından üniversite öğrencileri ile yapılan çalışmalarda bilişüstü beceriler ve farkındalık ile akademik öz yeterlik arasında anlamlı bir ilişki saptanmıştır. Tunca ve Alkın-Şahin (2014), öğretmen adaylarının akademik öz yeterlik 
inançları ile bilişötesi öğrenme stratejileri arasında orta düzeyde olumlu ilişki olduğunu bulmuşlardır. Araştırmada ulaşılan bu sonuç, ortaokul öğrencilerinin akademik öz yeterlik algılarının okuma stratejileri bilişüstü farkındalıklarını desteklediği şeklinde yorumlanabilir.

Araştırma kapsamında yapılan alan yazın taraması ve elde edilen bulgular doğrultusunda aşağıdaki öneriler getirilmiştir:

Akademik öz yeterlik ve okuma stratejileri bilişüstü farkındalık arasındaki ilişki, bu özelliklerin birbiriyle etkileşim içinde olduğunu göstermektedir. Akademik başarı ve diğer öğrenme ürünleri üzerindeki olumlu etkileri araştırmalar tarafından kanıtlanmış olan bu iki özelliğin önemi, hizmet öncesi ve hizmet içi öğretmen eğitiminde vurgulanmalı ve geliştirilmesi konusunda öğretmen adaylarına ve öğretmenlere tutum ve beceri kazandırılmalıdır.

Akademik öz yeterlikle ilgili çalışmaların genellikle üniversite düzeyinde gerçekleştirildiği dikkat çekmektedir. Öğrencilerin akademik öz yeterlik inançlarının bütün eğitim kademelerinde incelenmesine ihtiyaç duyulduğu düşünülmektedir. Ayrıca boylamsal çalışmalarla akademik öz yeterlik inançlarının gelişim sürecinin incelenmesinin ve elde edilen bulgular ışı̆̆ında akademik öz yeterliği destekleyici önlemlerin alınmasının yararlı olacağı düşünülmektedir.

Ortaokul öğrencilerinin hem akademik öz yeterlik inançlarının hem de okuma stratejileri bilişüstü farkındalıklarının sınıf düzeyi arttıkça düşüş göstermesinin nedenleri araştırılmalı ve öğrenme öğretme süreçleri bu özelliklerin gelişimini destekleyecek şekilde yapilandırılmalıdır.

Öz yeterlik inançlarının pek çok öğrenme üzerindeki olumlu etkisi, bu özelliğin bütün eğitim kademelerinde üzerinde durulmasının gerekliliğini ortaya koymaktadır. Temel 
eğitimden itibaren öğrencilerin öz yeterlik inançlarını destekleyen kaynakların iyi yapılandırılmasının eğitim programlarının etkililiğini artırmada da katkı sağlayacağı söylenebilir.

Öğrencilerin temel eğitimden itibaren stratejik öğrenmeyi ve okumayı öğrenmeleri desteklenerek bütün alanlardaki akademik başarılarının artırılabileceği düşünülmektedir.

\section{Makalenin Bilimdeki Konumu (Yeri)}

Eğitim Bilimleri, Eğitim Programları ve Öğretim

\section{Makalenin Bilimdeki Özgünlüğü}

Akademik öz yeterlikle ilgili yurt içi alanyazın incelendiğinde, bu konunun genellikle üniversite düzeyindeki öğrencilerle araştırıldığı görülmektedir. İlkokul ve ortaokul öğrencilerinin akademik öz yeterlik inançlarını inceleyen az sayıda çalışma bulunmaktadır. Bu araştırmanın bu konuda katkı sunacağı düşünülmektedir. Ayrıca akademik öz yeterlik algısı ile okuma stratejileri bilişüstü farkındalık arasındaki ilişkinin incelenmesi de ilgili alanyazına katkı sunması bakımından önemli görülmektedir.

\section{Kaynaklar}

Açıkgöz, K. Ü. (1998). Etkili öğrenme ve öğretme. İzmir: Kanyılmaz Matbaası.

Akbaş, A. ve Çelikkaleli, Ö. (2006). Sınıf öğretmeni adaylarının fen öğretimi özyeterlik inançlarının cinsiyet, öğrenim türü ve üniversitelerine göre incelenmesi. Mersin Üniversitesi Ĕ̈itim Fakültesi Dergisi, 2(1), 98-110. 
Akın, A., Abacı, R., Çetin, B. (2007). Bilişötesi farkındalık envanteri’nin Türkçe formunun geçerlik ve güvenirlik çalışması. Kuram ve Uygulamada Eğitim Bilimleri, 7 (2), 655680.

Akın, E., Çeçen, M. A. (2014). Ortaokul öğrencilerinin okuma stratejileri üstbilişsel farkındalık düzeylerinin değerlendirilmesi. Turkish Studies-International Periodical for the Languages, Literature and History of Turkish or Turkic. 9/8, 91-110.

Akyol, H. (2006). Türkçe öğretim yöntemleri. Ankara: Kök Yayınc1lık.

Atay, A. D. (2014). Ortaokul ögrencilerinin fen öğrenmeye yönelik motivasyon düzeylerinin ve üstbilişsel farkındalıklarının incelenmesi. (Yayımlanmamış Yüksek Lisans Tezi). Adnan Menderes Üniversitesi Fen Bilimleri Enstitüsü, Aydın.

Ateş, A. (2013). Üniversite öğrencilerinin okuma stratejileri üstbilişsel farkındalık düzeyleri (İnönü Üniversitesi Örneği). Uluslararası Türkçe Edebiyat Kültür Eğitim Dergisi, 2/4, $258-273$.

Aydın, S. (2014). Öğretmen adaylarının başarı amaç yönelimleri ve akademik özyeterliklerinin yapısal eşitlik modeliyle incelenmesi. Turkish Studies- International Periodical For The Languages, Literature and History of Turkish or Turkic, 9/2, 221230.

Bağçeci, B., Döş, B., Sarıca, R., (2011). İlköğretim öğrencilerinin üstbilişsel farkındalık düzeyleri ile akademik başarısı arasındaki ilişkinin incelenmesi. Mustafa Kemal Üniversitesi Sosyal Bilimler Enstitüsü Dergisi, 8(16), 551-566.

Baker, L., Brown, A.L. (1984), Metacognitive skills and reading. In R. Barr, M.L. Kamil, P. Mosenthal, P.D. Pearson (Eds.), Handbook of reading research, (2), s.353-394. White Plains, NY: Longman. 
Bandura, A. (1977). Self-Efficacy: Toward a unifying theory of behavioral change. Psychological Review, 84 (2), 191-215.

Bandura, A. (1994). Self-efficacy. In V. S. Ramachaudran (Ed.), Encyclopedia of human behavior (Vol. 4, pp. 71-81). New York: Academic Press. (Reprinted in H. Friedman Bandura, A. (1997). Editorial. American Journal of Health Promotion, 12(1), 8-10.

Bandura, A. (1999). Social cognitive theory of personality. Handbook of personality: Theory and research, 154-196.

Bandura, A. (2002). Exercise of personal and collective efficacy in changing societies. In A. Bandura (Ed.), Self efficacy in changing societies. Cambridge: Cambridge University Press, Transferred to digital printing.

Bandura, A., Barbaranelli, C., Caprara, G. V., Pastorelli, C. (1996). Multifaceted impact of self-efficacy beliefs on academic functioning. Child Development, 1206-1222.

Bloom, B. S. (2012). Insan nitelikleri ve okulda ögrenme. (Çev. D. A. Özçelik). Ankara: Pegem Akademi

Bruning, R. H.,Schraw, G. J. ve Norby, M. M. (2014). Bilişsel psikoloji ve öğretim. (Çev. Edit. Z. N. Ersözlü, R. Ülker). Ankara: Nobel Yayıncılık.

Bulut, S., Ertem, G., \& Sevil, Ü. (2009). Hemşirelik öğrencilerinin eleştirel düşünme düzeylerinin incelenmesi. Dokuz Eylül Üniversitesi Hemşirelik Yüksekokulu Elektronik Dergisi, 2(2), 27-38.

Büyüköztürk, Ş. (2010). Sosyal bilimler için veri analizi el kitabı. Ankara: Pegem Yayıncılık.

Caprara, G. V., Barbaranelli, C., Steca, P., Malone, P. S. (2006). Teachers' self-efficacy beliefs as determinants of job satisfaction and students' academic achievement: A study at the school level. Journal of School Psychology, 44(6), 473-490. 
Çetin, B. (2013). Çocuklar için öz-yeterlik ölçeğinin ilköğretim 4. ve 5. sınıf öğrencilerinin akademik başarısını yordaması. Kastamonu Eğitim Dergisi, 21(3), 1117-1132.

Demirağ, S. (2015). Öğrencilerin akademik öz-yeterliklerinin yetenek, ortam ve eğitim kalitesine göre karşılaştırılması. Ĕgitim ve Öğretim Araştırmaları, 4/1, 315-323

Demirel, Ö. (2003). Türkçe ve sınıf öğretmenleri için Türkçe öğretimi. Ankara: Pegem Yayınc1lık.

Diseth, Â. (2011). Self-efficacy, goal orientations and learning strategies as mediators between preceding and subsequent academic achievement. Learning and Individual Differences, 21, 191-195.

Ekici, G. (2012). Akademik öz-yeterlik ölçeği: Türkçeye uyarlama, geçerlik ve güvenirlik çalışması. Hacettepe Üniversitesi Eğitim Fakültesi Dergisi, 43(43).

Evran, S., Yurdabakan (2013). İlköğretim 6, 7 ve 8. sınıf öğrencilerinin bilişüstü farkındalık düzeylerinin incelenmesi. Eğitim ve Öğretim Araştırmaları Dergisi, 2(1), 213-220.

Fırat D. Ş. (2010). Sınıf öğretmeni adaylarının akademik özyeterlik algılarının çeşitli değişkenler açısından incelenmesi. Abant İzzet Baysal Üniversitesi Dergisi, 10, 1.

Güneş, F. (2007). Türkçe öğretimi ve zihinsel yapılandırma. Ankara: Nobel Yayın.

Güngören, S. 2009. The effect of grade level on elementary school students'motivational beliefs in science. Yayımlanmamış yüksek lisans tezi, Ortadoğu Teknik Üniversitesi, Ankara.

Hazır Bıkmaz, F. (2006). Öz yeterlik inançları. Y. Kuzgun, D. Deryakulu (Edit.), Eğitimde bireysel farklılıklar. Ankara: Nobel Yayınc1lı. 
Hermita, M. ve Thamrin, W. P. (2015). Metacognition toward Academic Self-efficacy among Indonesian Private University Scholarship Students. Procedia-Social and Behavioral Sciences, 171, 1075-1080.

Honicke, T., Broadbent, J. (2016). The influence of academic self-efficacy on academic performance: A systematic review. Educational Research Review, 17, 63-84.

Hoy, A. W. ve Spero, R. B. (2005). Changes in teacher efficacy during the early years of teaching: A comparison of four measures. Teaching and Teacher Education, 21(4), 343-356.

Jacobs, J. E. ve Paris, S. G. (1987). Children's metacognition about reading: Issues in definition, measurement, and instruction. Educational Psychologist, 22(3-4), 225278.

Kalaycı, Ş. (2010). SPSS uygulamalı çok değişkenli istatistik teknikleri. Ankara: Asil Yayın.

Kana, F. (2014). Ortaokul öğrencilerinin üstbiliş okuma startejileri farkındalık düzeyleri. Erzincan Üniversitesi Eğitim Fakültesi Dergisi, 16, 1, 100- 120.

Kandemir, M. (2014). Akademik ertelemenin yordayıcıları: Sorumluluk, başarı/başarısızlığa yönelik yükleme stilleri ve akademik öz yeterlik inançları. Eğitim ve Bilim, 39, 171.

Karaarslan, G. ve Sungur, S. 2011. Elementary students' self-efficacy beliefs in science: Role of grade level, gender, and socio-economic status. Science Education International, 22, 72-79.

Karasar, N. (2004). Bilimsel araştırma yöntemi. Ankara: Nobel.

Karatay, H. ( 2009). Okuma Stratejileri Bilişsel Farkındalık Ölçeği. Abant İzzet Baysal Üniversitesi Sosyal Bilimler Enstitüsü Dergisi, 2 (19), 58-80. 
Karatay, H. ( 2010). İlköğretim öğrencilerinin okuduğunu kavrama ile ilgili bilişsel farkındalıkları. Türklük Bilimi Araştırmaları, 27(27), 457-475.

Kaya, N. B., Fırat, T. (2011) İlköğretim 5. ve 6. sınıf öğrencilerinin öğrenme-öğretme sürecinde üstbilişsel becerilerinin incelenmesi. Celal Bayar Üniversitesi Eğitim Fakültesi Dergisi, (1), 56- 70.

Koç, C., Karabağ, S. (2013). İlköğretim ikinci kademe (6-8. sınıf) öğrencilerinin bilişüstü yetileri ile başarı yönelimlerinin incelenmesi. Education Sciences, 8(2), 308-322.

Kurbanoğlu, N. I. ve Takunyac1, M. 2012. Relationship between anxiety, attitude and selfefficacy beliefs of high schools students towards mathematics course. International Journal of Human Sciences, 9, 110-130.

Linnenbrink, E. A., Pintrich, P. R. (2003). The role of self-efficacy beliefs in student engagement and learning in the classroom. Reading \& Writing Quarterly, 19: 119137.

Memiş, A., Arıcan, H. (2013). Beşinci sınıf öğrencilerinin matematiksel üstbiliş düzeylerinin cinsiyet ve başarı değişkenleri açısından incelenmesi. Karaelmas Eğitim Bilimleri Dergisi, 1(1), 76-93.

Mokhtari, K. ve Reichard, C. A. (2002). Assessing students' metacognitive awareness of reading strategies. Journal of Educational Psychology, 94, 2, 249-259.

Muris, P. (2001). A brief questionnaire for measuring self-efficacy in youths. Journal of Psychopathology and Behavioral Assessment, 23(3), 145-149.

Noushad, P.P. (2008). Cognition about cognitions: The theory of metacognition. Online Submission. 23 pp. Erişim Tarihi: 25.06.2016, http://files.eric.ed.gov/fulltext/ED502151.pdf 
Oğuz, A. (2009). Sınıf öğretmeni adaylarının akademik öz yeterlik inançları. VIII. Ulusal Sınıf Öğretmenliği Ĕ̈itimi Sempozyumu, 21-23 Mayıs 2009/ Eskişehir Osmangazi Üniversitesi, Eskişehir.

Oğuz, A. (2012). Sınıf öğretmeni adaylarının akademik öz yeterlik inançları. Anadolu Journal of Educational Sciences International, 2 (2), 15-28.

Oluk, S., Başöncül, N. (2009). İlköğretim 8. sınıf öğrencilerin üstbiliş okuma stratejilerini kullanma düzeyleri ile fen teknoloji ve Türkçe ders başarıları üzerine etkisi. Kastamonu Eğitim Dergisi, 17(1), 183-194.

Öncü, H. (2012). Akademik Özyeterlik Ölçeğinin Türkçe’ye Uyarlanması. Ahi Evran Üniversitesi Kırşehir Eğitim Fakültesi Dergisi, 13(1).

Pajares, F. (1996). Self-efficacy beliefs in academic settings. Review of Educational Research, 66, 4, 543-578.

Pajares, F. (2002). Gender and perceived self-efficacy in self-regulated learning. Theory into Practice, 41,2, 116- 125.

Pajares, F. (2012). Motivational role of self-efficacy beliefs in self-regulated learning. D. H. Schunk \& B. J. Zimmerman (Eds.), Motivation and self regulated learning. New York: Routledge.

Pajares, F., ve Miller, M. D. (1994). Role of self-efficacy and self-concept beliefs in mathematical problem solving: A path analysis. Journal of educational psychology, 86(2), 193.

Phan, H. P. 2012. Relations between informational sources, self-efficacy and academic achievement: A developmental approach. Educational Psychology, 32, 81-105. 
Polat, M., Dilekmen, M., Yasul, A. F. (2015). Öğretmen adaylarının okula yabancılaşma ve akademik öz-yeterlik: Bir Chaıd analizi incelemesi. Uluslararası Eğitim Bilimleri Dergisi, 2, 4, 214-232.

Sakız, G. (2013). Başarıda anahtar kelime: Öz-yeterlik. Uludă̆ Üniversitesi Eğitim Fakültesi Dergisi, 26 (1), 185-209.

Schraw, G. (1998). Promoting general metacognitive awareness. Instructional Science, 26, 113-125.

Schunk, D. H., Mullen, C. A. (2012). Self- efficacy as an engaged learner. In S. L. Christenson, A. L. Reschly ve C. Wylie (Eds.), Handbook of research on student engagement, (pp. 219-235). New York: Springer.

Schunk, D. H., Pajares, F. (2009). Self-Efficacy Theory. In Kathryn R. Wentzel \& Allan Wigfield (Eds.), Handbook of motivation at school. New York: Routledge.

Schunk, D. H., Zimmerman, B. J. (2007). Influencing children's self-efficacy and selfregulation of reading and writing through modeling. Reading and Writing Quarterly, $23,7-25$.

Schunk, D. H., Pajares, F. (2002). The development of academic self-efficacy. In A. Wigfield \& J. S. Eccles (Eds.), Development of achievement motivation. London: Academic Press.

Schunk, D.H., Pintrich, P.R., Meece, J.L., (2010). Motivation in education. Third Edition. New Jersey: Pearson Education.

Slavin, R. E. (2012). Eğitim psikolojisi. (Çev. Edit. G. Yüksel). Ankara: Nobel Yayıncılık. 
Şeker, S. S. (2014). The examınation of the relationship between the level of preservice music teachers academic self-efficacy and attitudes towards instrumental practise. Fine Arts, 9 (3), 135-149.

Tabancalı, E., Çelik, K. (2013). Öğretmen adaylarının akademik öz yeterlikleri ile öğretmen öz yeterlikleri arasındaki ilişki. International Journal of Human Sciences, 10, 1, $1167-1184$.

Tavakolizadeh, J., Tabari, J., Akbari, A. (2015). Academic self-efficacy: predictive role of attachment styles and meta-cognitive skills. Procedia - Social and Behavioral Sciences, 171, $113-120$.

Telef, B. B., Karaca, R. (2011). Ergenlerin öz-yeterliklerinin ve psikolojik semptomlarının incelenmesi. Mustafa Kemal Üniversitesi Sosyal Bilimler Enstitüsü Dergisi. 8 (16), 499-518.

Telef, B. B. ve Karaca, R. (2012). Çocuklar İçin Öz-yeterlik Ölçeğinin geçerlik ve güvenirlik çalışması. Buca Ĕ̆itim Fakültesi Dergisi, 32, 169-187.

Tok, H., Özgan, H., Döş, B. (2010). Assessıng metacognitive awareness and Learning strategies as positive predictors for success in a distance learning class. Mustafa Kemal Üniversitesi Sosyal Bilimler Enstitüsü Dergisi, 7(14), 123-134.

Tschannen-Moran, M., Johnson, D. (2011). Exploring literacy teachers' self-efficacy beliefs: Potential sources at play. Teaching and Teacher Education,27(4), 751-761.

Tunca, N., Alkın-Şahin, S. (2014). Öğretmen adaylarının bilişötesi (üst biliş) öğrenme stratejileri ile akademik öz yeterlik inançları arasındaki ilişki. Anadolu Journal of Educational Sciences International, 4(1), 47-56. 
Usher, E. L. (2009). Sources of middle school students' self-efficacy in mathematics: A qualitative investigation. American Educational Research Journal, 46, 1, 275-314.

Usher, E. L. ve Pajares, F. (2006). Sources of academic and self- regulatory efficacy beliefs of entering middle school students. Contemporary Educational Psychology, 31, 125141.

Usher, E. L. ve Pajares, F. (2008). Self-efficacy for self-regulated learning a validation study. Educational and Psychological Measurement, 68, 3, 443-463.

Usher, E. L. ve Pajares, F. (2008). Sources of self- efficacy in schools: Critical review of the literatüre and future directions. Review of Educational Research, 78, 4, 751-796.

Yazıcıŏglu, Y. ve Erdoğan, S. (2014). SPSS uygulamalı bilimsel araştırma yöntemleri. Ankara: Detay Yayıncılık.

Yenilmez, K. (2016). Öğretmen adaylarının akademik öz-yeterlikleri ve matematik öğretimine yönelik öz-yeterliklerinin bazı değişkenler açısından incelenmesi. Dicle Üniversitesi Ziya Gökalp Ĕ̆itim Fakültesi Dergisi, 29, 324-322.

Yıldırım, A., Doğanay, A., Türkoğlu, A. (2009). Okulda başarı için ders çalışma ve öğrenme yöntemleri. Ankara: Seçkin.

Yıldız, D. (2015). 8. Sınıf öğrencilerinin bilişüstü farkındalık ve akademik öz yeterlik düzeyleri, motivasyonel inançları ve TEOG sınavı Türkçe puanları: Bir yapısal eşitlik modeli denemesi. Tarih Okulu Dergisi (TOD), 8, XXIII, 41-61.

Yılmaz, M., Gürçay, D. ve Ekici, G. (2007). Akademik özyeterlik ölçeğinin Türkçe’ye uyarlanması. Hacettepe Üniversitesi Ĕ̆itim Fakültesi Dergisi,33(33).

Zhang, L. J. ve Wu, A. (2009). Chinese senior high school EFL students' metacognitive awareness and reading-strategy use. Reading in a Foreign Language, 21, 1, 37-59. 
Zimmerman, B. J. (1989). A social cognitive view of self-regulated academic learning. Journal of Educational Psychology, 81, 3, 329-339.

Zimmerman, B. J. (2000). Self-efficacy: An essential motive to learn. Contemporary Educational Psychology, 25, 82-91.

Zimmerman, B. J., Bandura, A. ve Martinez-Pons, M. (1992). Self-motivation for academic attainment: The role of self-efficacy beliefs and personal goal setting. American Educational Research Journal, 29, 3, 663-676. 